\title{
Audit of Antibiotic Uses in Pediatric Intensive Care Unit of Assiut University Hospital
}

\author{
AMANY M. SAKHR, M.Sc.; MOHAMED M.H. GHAZALY, M.D. and ISMAIL L. MOHAMAD, M.D. \\ The Department of Pediatrics, Faculty of Medicine, Assiut University, Egypt
}

\begin{abstract}
Background: Antimicrobial therapy is common among patients hospitalized in Intensive Care Units (ICUs) compared with patients in the general hospital population. Overuse and inappropriate use of antibiotics are key factors contributing to emergence of multidrug-resistant pathogens, so surveillance of their use is important.
\end{abstract}

Aim of Study: To assess the appropriateness of antimicrobial prescription according to clinical and microbiological findings, and formulary guidelines.

Patients and Methods: The study included 162 patients who stayed longer than 24 hours in the pediatric ICU.

Results: All of the total 162 patients admitted in PICU during the study period received antibiotics: Of them $30.8 \%$ $(\mathrm{n}=50)$ prophylactically, $70.3 \%(\mathrm{n}=114)$ empirically, and $11.7 \%(n=19)$ therapeutically. $18.5 \%$ of patients received one antibiotic, and $81.5 \%$ received two or more antimicrobial combination.

Conclusion: This study provides valuable insight to antibiotics usage in PICU of developing country, which shows that antibiotics are prescribed universally in our PICU. Strategies to assess the need for antibiotic use are needed.

Key Words: Antibiotic use - infection - Pediatric Intensive Care Unit.

\section{Introduction}

ANTIMICROBIAL therapy is common among patients hospitalized in ICUs as they have more chronic comorbid illness and acute illnesses, injuries, and surgical procedures compared with patients in the general hospital population. In addition, patients in ICUs are often exposed to invasive devices or procedures that provide a portal of entry for microorganisms. Those patients are also susceptible to colonization and infection with nosocomial pathogens. At times these nosocomial path-

Correspondence to: Dr. Amany M. Sakhr, E-Mail: amany.sakhr@yahoo.com ogens may be antimicrobial-resistant organisms, and thus, may be difficult to treat $[\mathbf{1 , 2}]$.

Hospital Acquired Infections (HAIs) have been reported to affect $16-23.6 \%$ of patients admitted in PICUs [3-5]. Infections caused by antimicrobialresistant bacteria are associated with higher mortality rates $[6,7]$.

\section{Subjects and Methods}

A total number of 243 patients were admitted to PICU from 1 st April 2016 to 30 September 2016, 81 of them who stayed for less than 24 hours were excluded from the study.

Study site:

Pediatric ICU at Assiut University Children Hospital, Tertiary, Care Center.

Inclusion criteria:

- Infants and children from age of one month to 17 years old.

- Patients who stayed longer than 24 hours in the PICU.

\section{Data collection:}

Reviewing sheets and medical records of 162 patients who stayed longer than 24 hours in the PICU from 1 st April 2016 to 30 September 2016. Each admission was considered a patient encounter.

Data collected included demographic variables (age, gender), clinical, laboratory, and microbiological data. For each patient the cumulative number of antibiotics prescribed during the length of stay in PICU was recorded. The indications of antibiotics were categorized as prophylaxis, empirical, and therapeutics. 


\section{Statistical analysis:}

The data were entered and analyzed using statistics computer program. Unpaired $t$-tests were used to compare means and Chi square tests of proportion to compare categorical variables. A two-tailed $p<0.05$ was considered statistically significant, and $p<0.01$ was considered statistically highly significant.

\section{Results}

Demographic data of studied patients are described in (Table 1). The median age of our sample was 18 months. Mean length of stay in PICU was 7.25 days. The most common reasons for admission to the PICU was respiratory distress $(55.5 \%)$.

\section{Antibiotics surveillance data:}

All patients (100\%) admitted to our PICU received antibiotics, $30(18.5 \%)$ received one antimicrobial agent, and $132(81.5 \%)$ received two or more antimicrobial agents. Of them 114 patients received empirical antibiotics. 50 patients received prophylactic antibiotics. Only 19 patients received targeted antibiotics according to the result of culture and sensitivity. We could not determine the indication for $12(3.14 \%)$ prescriptions (Table 2$)$.

The 10 most commonly prescribed antimicrobial agents during the study period are listed in Fig. (1). Overall, Ampicillin/sulbactam, Ceftriaxone, and vancomycin were the three most commonly used antimicrobials, accounting for $56.3 \%$ of the total antimicrobial prescriptions during the study period.

Fig. (2) shows results of cultures obtained during period of the study. More than $80 \%$ of blood cultures obtained were positive. More than $70 \%$ of tracheal aspirate done during the study period were positive. Also about $80 \%$ of urine cultures obtained during the study period were positive. The single cerebrospinal fluid culture which had been done during the study period was negative, the same was for burn swab.

Fig. (3) shows the commonest isolated organisms from cultures of the studied group. Klebsiella pneumonia was the commonest organism isolated from cultures obtained during the study period, followed by Coagulase-negative staphylococci and Acinetobacter baumanni. The most common microorganisms isolated from tracheal aspirate cultures were Klebsiella pneumonia, Acinetobacter baumanni, and Pseudomonas aeruginosa. Coagulase-negative staphylococci were frequently isolated from blood cultures.
Six $(33.3 \%)$ of 18 positive tracheal aspirate cultures were resistant to all antibiotics, compared to $2(10 \%)$ of 20 positive blood cultures were resistant to all antibiotics $(p=0.08)$.

Fig. (4) shows that $22.8 \%$ of the studied patients had hospital acquired infection, 16 patients had ventilation acquired pneumonia, 13 patients had nosocomial sepsis, and 8 patients had hospital acquired urinary tract infection.

Table (1): Demographic data of the studied group.

\begin{tabular}{|c|c|c|}
\hline Variables & Characteristic & Total $\mathrm{N}=162$ \\
\hline \multirow[t]{2}{*}{ Gender } & \multirow{2}{*}{$\begin{array}{l}\text { Male } \\
\text { Female }\end{array}$} & $81(50 \%)$ \\
\hline & & $81(50 \%)$ \\
\hline Age & $\begin{array}{l}\text { Median age in years } \\
(\text { mean } \pm \text { std })\end{array}$ & $1.5(3.4 \pm 4.5)$ \\
\hline \multirow[t]{4}{*}{ Age categories } & Infants (>1mo-12mo) & $63(38.9 \%)$ \\
\hline & Toddlers (12mo-24mo) & $28(17.3 \%)$ \\
\hline & Children (>2yrs-12yrs) & $54(33.3 \%)$ \\
\hline & Adolescents (>12yrs) & $17(10.5 \%)$ \\
\hline Weight & $\begin{array}{l}\text { Median weight in } \mathrm{kg} \\
(\text { mean } \pm \text { std })\end{array}$ & $10(14.75 \pm 14.8)$ \\
\hline $\begin{array}{l}\text { Length of stay in } \\
\text { PICU }\end{array}$ & $\begin{array}{l}\text { Median length of stay in } \\
\text { PICU in days (mean } \pm \text { std) }\end{array}$ & $5(7.25 \pm 6.96)$ \\
\hline \multirow[t]{3}{*}{ Invasive devices } & Endotracheal tube & $123(75.9 \%)$ \\
\hline & Foley catheter & $125(77 \%)$ \\
\hline & Central venous catheter & $13(8 \%)$ \\
\hline Nutrition & Parenteral nutrition & $102(62.9 \%)$ \\
\hline \multirow{4}{*}{$\begin{array}{l}\text { Reasons for } \\
\text { admission }\end{array}$} & \multirow{3}{*}{$\begin{array}{l}\text { Respiratory distress } \\
\text { Disturbed conscious level } \\
\text { Peri-operative }\end{array}$} & $90(55.5 \%)$ \\
\hline & & $35(21.6 \%)$ \\
\hline & & $11(6.8 \%)$ \\
\hline & Others & $26(16 \%)$ \\
\hline Survival & $\begin{array}{l}\text { Discharged from the PICU } \\
\text { alive }\end{array}$ & $65(40.1 \%)$ \\
\hline $\begin{array}{l}\text { Abbreviations: } \\
\text { std : Standard Deviation. } \\
\text { kg : Kilograms. }\end{array}$ & $\begin{array}{l}\text { PICU : Pediatric I } \\
\text { mo : Month. } \\
\text { yrs : Years. }\end{array}$ & ensive Care Unit. \\
\hline
\end{tabular}

Table (2): Indications for antimicrobials therapy.

\begin{tabular}{lccc}
\hline Indication & $\begin{array}{c}\text { Number of } \\
\text { patients }(\%) \\
(\mathrm{n}=162)\end{array}$ & $\begin{array}{c}\text { Number of } \\
\text { Antimicrobial } \\
\text { Prescriptions }(\%) \\
(\mathrm{n}=382)\end{array}$ & $\begin{array}{c}\text { Median } \\
\text { treatment days } \\
(\text { mean } \pm \text { std) }\end{array}$ \\
\hline Empiric & $114(70.3 \%)$ & $263(68.9 \%)$ & $5(5.5 \pm 4.0)$ \\
Prophylactic & $50 \quad(30.8 \%)$ & $75 \quad(19.6 \%)$ & $4(4.8 \pm 3.3)$ \\
Targeted & $19 \quad(11.7 \%)$ & $32(8.4 \%)$ & $7(9.3 \pm 8.1)$ \\
Unknown & $12(7.4 \%)$ & $12(3.1 \%)$ & $2(3.5 \pm 2.1)$ \\
\hline $\begin{array}{l}\text { Note: } \\
\text { *: Number of patients in each category is greater than } 162 \text { because } \\
\text { some patients received antimicrobial agents for more than one } \\
\text { indication. }\end{array}$ \\
$\begin{array}{l}\text { Abbreviations: } \\
\text { std: Standard Deviation. }\end{array}$
\end{tabular}




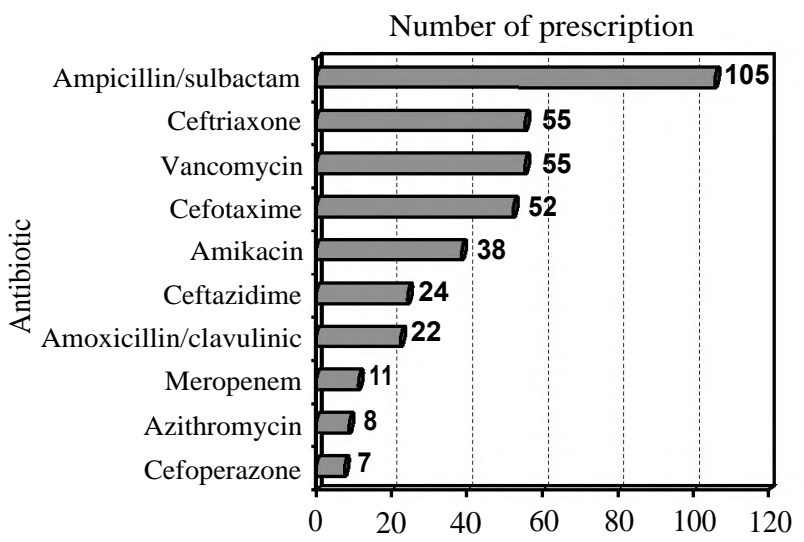

Fig. (1): The 10 most commonly prescribed antimicrobial agents in the study.

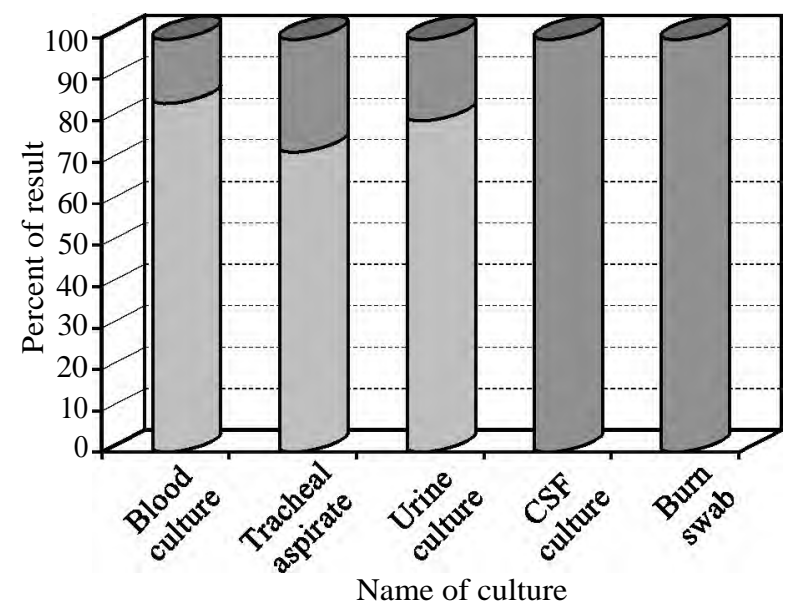

Negative cultures

Positive cultures

Fig. (2): Cultures done for patients in PICU and their results.

Abbreviation:

CSF: Cerebrospinal Fluid.

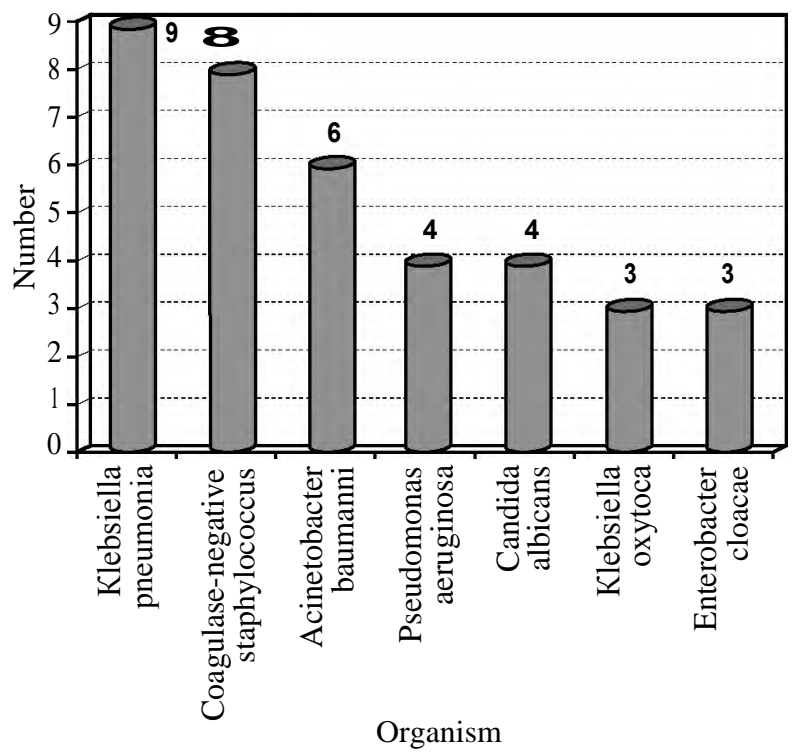

Fig. (3): The commonest isolated organisms from cultures of studied patients.

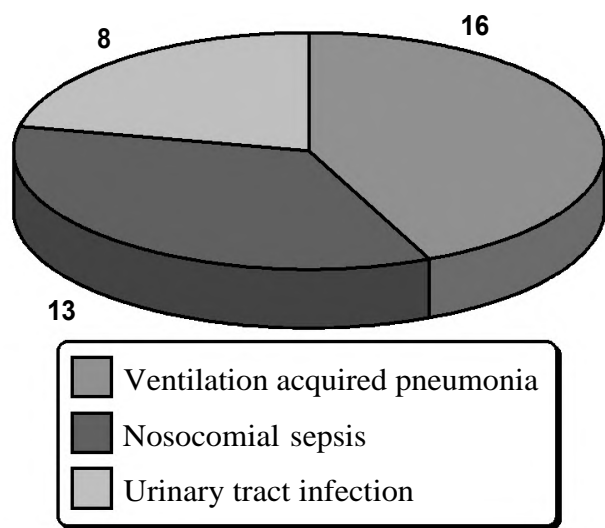

Fig. (4): Number of patients who had hospital acquired infection.

\section{Discussion}

Descriptive data on antimicrobial use is important because it would reveal the extent of use and temporal trends of antimicrobial use in a PICU.

Our study highlights some very important points. The entire patient population $(100 \%)$ received antibiotics as prophylaxis or empirical therapy compared to other studies that reported antibiotic usage of $36-100 \%$ in their PICUs [2, 8-10].

Blood cultures had been obtained from 24 patients during the study period. The majority $(83.3 \%)$ of them were positive which is significantly higher than negative results $(16.7 \%)(p<0.0001)$. Qalab and colleagues reported that the blood cultures were positive in $14 \%$ [2].

Tracheal aspirates had been obtained from 25 patients during the study period, $18(72 \%)$ of these tracheal aspirates were positive which is significantly higher than negative results $(28 \%)$ ( $p=$ $0.002)$. Qalab and colleagues reported that the tracheal aspirates were positive in $24 \%$ [2]

Six (33 .3\%) of 18 positive tracheal aspirate cultures showed multi-drug resistant bacteria to all available antibiotics, compared to $2(10 \%)$ of 20 positive blood cultures were resistant to all antibiotics $(p=0.08)$.

Multi-drug resistant pseudomonas aeruginosa was isolated in five positive cultures, where multidrug resistant Klebsiella species was isolated in four positive cultures.

Our study shows that empirical therapy was prescribed to the majority $(70.3 \%)$ of the patients. This might have been due to the reason of limited microbiologic yield and the critical condition of the patients admitted to PICU. A similar study of 
antibiotic use in PICU of Canada showed 27-40\% usage of empiric antibiotic treatment [9] while another study by Ding et al., from China showed that $72 \%$ of their patients in PICU received empiric antibiotic treatment [8]. Qalab reported that $42 \%$ of patients in PICU received empiric antibiotic treatment [2].

In the present study misuse of antibiotics was observed in 12 patients $(7.4 \%)$ without definite indication for antibiotics. Josiah reported that 8 patients $(6 \%)$ received 18 antimicrobial prescriptions while they were not indicated for antibiotic use [11]

The most three common antimicrobial combinations used for empiric treatment were vancomycin and Ceftriaxone; Ampicillin/sulbactam, and Amikacin; and Ampicillin/sulbactam, and Cefotaxime, which is consistent with the unit's treatment protocols for treating sick patients.

Grohskopf and colleagues reported that cefazolin, vancomycin, and cefotaxime were the antimicrobial agents most frequently prescribed in their PICU [12]. Josiah also reported that vancomycin, gentamicin, and cefazolin were the antimicrobial agents prescribed most frequently [11]. Qalab and colleagues reported that cefazolin, meropenem, vancomycin, and ceftriaxone were the antimicrobial agents most frequently prescribed in their PICU [2].

Several studies have evaluated the prevalence and incidence of infections among children in Pediatric Intensive Care Units (PICUs). In a study done In Europe, incidence of Hospital Acquired Infections (HAIs) was $23.6 \%$ in Pediatric ICUs (PICU) [5] . In our study, 37 patients $(22.8 \%)$ of 162 patients who were admitted to PICU during the study period had hospital acquired infection, 16 patients had ventilation acquired pneumonia, 13 patients had nosocomial sepsis, and 8 patients had hospital acquired urinary tract infection.

\section{Conclusion:}

This study provides valuable insight to antibiotics usage in PICU of a developing country. Our results points that overuse of antibiotics exists in our PICU. There is the need for microbiological support for clinicians to increase the rate of appropriate prescription and discontinue empirical therapy as soon as possible. Increasing the number of pediatric infectious disease specialists, practical antimicrobial treatment guidelines, and continuing education for residents are also important to resolve the problem of inappropriate antimicrobial use.

\section{Financial support and sponsorship:}

Nil.

\section{Recommendations:}

Effective antimicrobial stewardship strategies that are easy to implement are needed. In addition, clinicians would benefit from a tool that helps them discriminate bacterial infections from nonbacterial infections and from systemic inflammatory response syndrome.

Residents and the fellows should be asked to complete an antimicrobial assessment form (AA) to document their rationale for starting antimicrobial therapy. This might remind pediatric intensivists to review antimicrobial therapies, especially empiric therapies, when the microbiologic data became available, thus, reducing the duration of antimicrobial therapy and possibly reducing the quantity (measured in grams) of antimicrobial consumpt.

Introduction of Infection preventionists and hospital epidemiologists will monitor and prevent healthcare-associated infections. They can also assist with monitoring and reporting of resistance, educating staff on the importance of appropriate antibiotic use, and implementing strategies to optimize the use of antibiotics.

Cultures must be performed before starting antibiotics with the help of well educated nurses. There is the need for microbiological support for clinicians to increase the rate of appropriate prescription and discontinue empirical therapy as soon as possible.

\section{References}

1- National Nosocomial Infections Surveillance System. National nosocomial infections surveillance (NNIS) system report, data summary from January 1992 through June 2004, issued october 2004. Am. J. Infect. Control, 32 (8): 470-85, 2004.

2- QALAB A., ANWAR UL HAQ R.K., SAYED A.A., KASHIF H. and SADIA S.: Evaluation of Antibiotic Use in Pediatric Intensive Care Unit of a Developing Country, 291-4, 2016.

3- JORAM N., De SAINT BLANQUAT L., STAMM D., LAUNAY E. and GRAS-Le GUEN C.: Healthcareassociated infection prevention in pediatric intensive care units: A review. Eur. J. Clin. Microbiol. Infect. Dis., 31: 2481-90, 2012.

4- URREA M., PONS M., SERRA M., LATORRE C. and PALOMEQUE A.: Prospective incidence study of nosocomial infections in a pediatric Intensive Care Unit. Pediatr. Infect. Dis. J., 22: 490-4, 2003. 
5- ROSENTHAL V.D., MAKI D.G., MEHTA Y., et al.: International Nosocomial Infection Control Consortium (INICC) report, data summary of 43 countries for 2007 2012. Device-associated module. Am. J. Infect. Control, 42: 942-56, 2014

6- EVANS H.L., LEFRAK S.N., LYMAN J., et al.: Cost of gram-negative resistance. Crit. Care Med., 35 (1): 89-95, 2007.

7- DING H., YANG Y., LU Q., WANG Y., CHEN Y., DENG L., et al.: Five-year surveillance of antimicrobial use in Chinese Pediatric Intensive Care Units. J. Trop. Pediatr., 54: 238-42, 2008.

8- DING H., YANG Y., CHEN Y., WANG Y., FAN S. and SHEN X.: Antimicrobial usage in paediatric intensive care units in China. Acta. Paediatr., 97: 100-4, 2008.
9- BLINOVA E., LAU E., BITNUN A., COX P., SCHWARTZ S., ATENAFU E., et al.: Point prevalence survey of antimicrobial utilization in the cardiac and Pediatric Critical Care Unit. Pediatr. Crit. Care Med., 14: e280-8, 2013

10- DING H., YANG Y., WEI J., FAN S., YU S., YAO K., et al.: Influencing the use of antibiotics in a Chinese pediatric Intensive Care Unit. Pharm. World Sci., 30: 787-93, 2008.

11- JOSIAH OLUSEGUN ALAMU: Evaluation of antimicrobial use in a Pediatric Intensive Care Unit, July, 24-33, 2009.

12- GROHSKOPF L.A., HUSKINS W.C., SINKOWITZCOCHRAN R.L., et al.: Use of antimicrobial agents in united states neonatal and Pediatric Intensive Care Patients. Pediatr. Infect. Dis. J., 24 (9): 766-73, 2005.

\section{مراجعة دواعى إستخدام المضادات الحيوية بوحلدة العناية المركزة

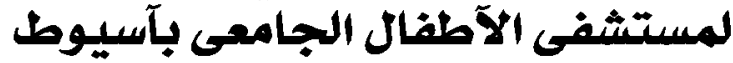

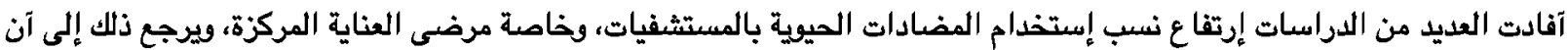

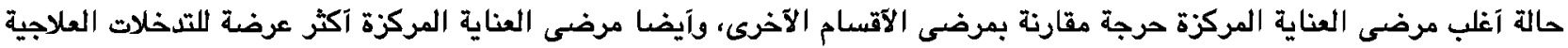

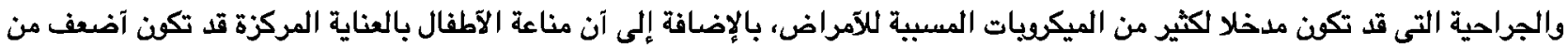
غيرهم مما يجعلهم آكثر عرضة لعدوى المستشفيات، والعدوى المقاومة للمضادات العيكية العيوية.

إن الهدف من إجراء تلك الرسالة هو إعطاء صودة واضحة عن إستخدام المضادات الحيوية بالعناية المركزة ودواعى إستخدامها، وعما إذا كان هناك سوء إستخدام لتلك الآسوية آَ آلا.

لقد تمت مراجعة الملفات الطبية الخاصة بجميع الآطفال الذين مكثوا بالعناية المركزة آكثر من آريع وعثرين ساعة، وعددهـم مائة وإثنان

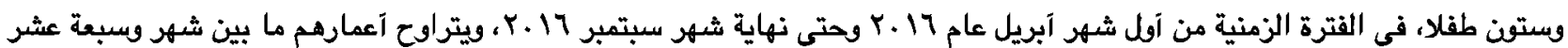

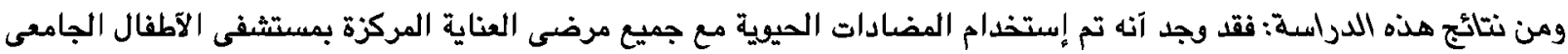

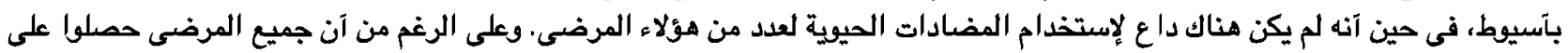

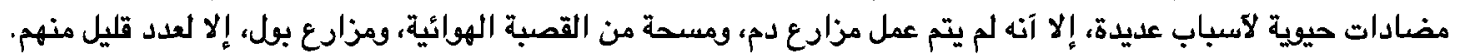

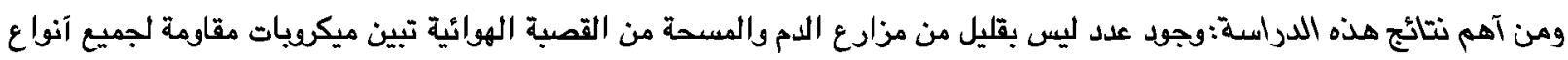

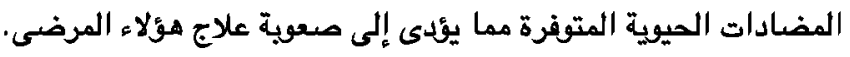

هناك آيضا نسبة من مرضى العناية المركزة قد آصابهم علدى المستشفيات، وآثر ذلك سلبيا على المرضى، مما يستدعى ضربدة الإهتمام بوحدة مكافحة علوى المستشفيات الحد من تلك الكناية العدوىى.

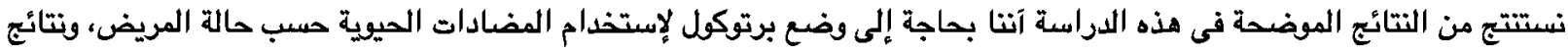
التحاليل المتوفرة، ولابد من نشر الوعى بين الآطباء فيما يخص المضادات الهيوية وضرورة تجنب الإستخدام الخاطئ لها في حصد عدم الإضرار 